\title{
The Economics of a College Education
}

\author{
Allan Ornstein \\ St. John's University, New York, USA \\ Email: allanornstein@yahoo.com
}

How to cite this paper: Ornstein, A. (2017) The Economics of a College Education. Open Access Library Journal, 4: e3812.

https://doi.org/10.4236/oalib.1103812

Received: July 7, 2017

Accepted: November 11, 2017

Published: November 14, 2017

Copyright $\odot 2017$ by author and Open Access Library Inc.

This work is licensed under the Creative Commons Attribution International License (CC BY 4.0).

http://creativecommons.org/licenses/by/4.0/

(c) () Open Access

\begin{abstract}
Given the cost of obtaining a college education in the US, resulting in the average debt for undergraduate students $(\$ 26,000)$ and for masters' students $(\$ 50,000)$, the question arises whether college (tuition and room and board) is worth the cost. Not all college students find jobs. There's a growing number who are under employed or unemployed. Those that do find jobs often do so at reduced salaries in the mist of stiff competition. The author raises the question whether the benefits of a college education outweighs the costs. The Ivy League colleges are institutions that have traditionally promoted privilege and power by educating the children of the upper class, not only in the US but also around the world. The history of admission into these elite colleges is reflected in the conflict between applicants who exhibit academic merit or ability versus privilege, social connections or alumni legacy. Hence the admission process has now become a balancing act between the academic student versus the well-rounded student, a euphemism for those students who lack academic qualifications. What criteria should be used for admission into Ivy League colleges? What form of excellence should govern the process? Who decides on the form of excellence? Should special consideration be given to poor or minority students in order to enhance diversity?
\end{abstract}

\section{Subject Areas}

Economics, Education

\section{Keywords}

College Tuition Costs, College Student Debt, State Universities, Underemployed College Graduates, Benefits of a College Education, The Value of a College Education

\section{Introduction}

Democratic societies tend to ignore differences in intelligence where possible; 
when it cannot be avoided, the blame is shifted to the institutions or agents of society. No group is supposed to be regarded as better or smarter than another group. Whenever differences in capacity are discussed in a democratic society, the politically correct view is that differences vary among individuals and not groups. In a heterogeneous society like ours, when we focus on differences in achievement or economic outcomes, the result can lead to a host of hotly contested issues. And when we compare group differences or outcomes, the debate can become highly emotional-focusing on differences in ability among different ethnic groups, accusations of racism, or using the race card as a means to stifle public discussion.

Given how American society has evolved, the ideal is to search for the golden mean which goes back to the ancient Greeks, and to achieve a balancing act which rewards merit and hard work and provides a floor or safety net for low-performing, slow running and weaker individuals. But despite this ideal standard for society, we are confronted with the harsh truth that this nation remains much more stratified than what its principles suggest. Moreover, there is very little movement form one class to another in American society. We would like to believe that through merit and hard work anyone can achieve the American dream. Our Founding Fathers rejected aristocracy and inherited privilege.

Yet we are heading toward the creation of a new aristocracy-much worse than the autocratic world that our Founding Fathers feared and tried to avoid. The new aristocracy is rooted in the rise of a new money class: Wall Street and the banking industry, the entertainment industry (including Hollywood stars, pop singers, and professional athletes) and the captains of industry. At the same time, we are witnessing the dismantling of the middle class which is the backbone of democracy. We are also beginning to question whether college is still the main avenue for achieving middle-class status, given the rising costs of tuition and debt incurred for attending college. For example, college tuition annually increased between 5 to 6 percent between 2000 and 2012, according to the College Board, running about 2 - 3 times the inflation rate for the same period.

\section{Topic 1: The Value of a College Education}

Since the turn of the twenty-first century, college graduates have seen their wages stagnate while two-thirds of all undergraduates graduate with an average debt of $\$ 26,000$ and masters' students compiled an average debt of over $\$ 50,000$. The total student debt in 2014 amounted to more than $\$ 1.2$ trillion, a sum greater than the combined US credit card debt and all auto loan debt.

The fact is 25 percent of millenials, young adults ages 18 to 34 , carry college debt and a third of these borrowers are considered delinquent in loan payment. Moreover, some two million Americans age 60 and older are still in debt due to unpaid student loans. The student debt among older people has increased from $\$ 8$ billion in 2005 to $\$ 43$ billion in 2014, indicating the effect of constant compounding debt and a fixed income as an adult. The interest on many loans can 
cause the debtor to spend more on interest than principal over time.

Students borrow heavily without thinking of the consequences or the financial pressure they might face after graduation. Not only does growing student debt have a detrimental effect on the ability of college graduates to afford a home mortgage, the Journal also reported that people under 40 with student loans have more other debt-credit cards, auto loans, etc.-and less net worth than their counterparts without student debt. As student debt gets heavier, it is safe to assume that other issues surface such as depression, low work morale, low job performance levels, less purchasing power and in turn a ceiling on economic growth. The worse scenario is to incur a lot of student debt and not graduate from college-more often the case among poor and working-class students than middle-class students.

What all this means is that people do not have an equal chance to succeed. Passing laws to eliminate discrimination is not enough. Policies must be implemented that remedy monetary disadvantages with which many people start with. In the US, that represents about one half of the student population who cannot afford college and most go into debt to attend college. Trying to compare colleges on how much debt their students accumulate or how much their students earn after graduating is misleading. The rating system is bound to be oversimplified and the information collected by colleges is varied and fuzzy. The need is to provide adequate opportunity for low-income and working-class students to reach their maximum potential and to fulfill their full range of excellence.

A rich society like ours should be able to ensure that all students who have earned a particular grade point average (say 90 percent or higher), can attend a state college for a nominal fee or free. Otherwise, society winds up squandering a great percentage of human potential and talent. Another option, less controversial, is to link student loan payments to future earnings. If someone goes into the Peace Corps or teaches, that is works in the human/social service area, part or most of the loan should be shouldered by the federal government. The exact amount could vary by years of service or other factors based on future income. Another method is to require all students at the beginning of their college experience to pay 3 to 5 percent of their future earnings for 20 years in a state or federal fund. This would serve as an insurance program for all college graduates despite their tuition costs.

Increasingly, a number of pundits are questioning the economic value of a college education. Given $\$ 50,000$ per year for four years (cost for college tuition and room and board for many private colleges), that is $\$ 200,000$ placed in a money market or insurance account at age 18 , compounded at $4 \%$ per year for 50 years $(22+45=67$ years, the age when Social Security starts), yields a better lifetime return ( $\$ 1.4$ million) than the difference earned between a college graduate and high school graduate (slightly more than $\$ 900,000)$. At $6 \%$ the yield is $\$ 3.7$ million and at $8 \%$ the yield is a whopping $\$ 9.4$ million or $\$ 8.5$ million more than the lifetime income between a college and high school graduate. Properly 
structured with an insurance company or with a financial advisor, federal tax can be delayed until distributions are made or even eliminated entirely.

Another way for questioning the value of a college education is to compare the cost of state universities with private ones. Consider four major state universities, and their annual tuition cost for in-state students for the year 2013/2014. (No other costs are considered such as room and board, registration fees, books, health insurance, etc.) University of North Carolina-Chapel Hill, \$5800; University of Wisconsin-Madison, \$9200; Ohio State University, \$9750; and University of Texas-Austin, $\$ 9000$ - $\$ 11,200$ depending on your field of study. Now compare these figures with the tuition of Ivy League schools: Harvard, $\$ 43,900$; Dartmouth, $\$ 45,500$; Yale, $\$ 45,800$; Columbia, $\$ 46,800$. Most state universities have their own website to explain in-state tuition policies. The candidate usually needs to be living in the state for at least a year and is financially independent from their out-of-state parents. Rules can vary for married students, veterans, and noncitizens.

When it comes to comparing average starting salaries between graduates from the above four state universities and the four Ivy League schools, the difference is about $\$ 10,000$ to $\$ 12,000$. But the educational institution has much less direct effect on salaries once we introduce other factors: supply-demand for the particular job, market pay rates for people doing similar work, regional location of the job, candidates IQ, personality, and work (or internship) experience, parents' network of friends and colleagues, etc. When these factors or variables are introduced the direct effect of the college on starting salaries is miniscule-often not worth the differences in total tuition costs. Then there is always the notion of luck or the unaccounted for variance. This factor alone may account for as much as 50 percent of the monetary outcomes, that is the difference in starting salaries and even lifetime earnings. The long and short of all the factors is simple: Predicting an individual's future capacity to perform on the job remains a hazardous undertaking, and considering only one factor (education) oversimplifies the process. When judging talent and ability, or someone's future performance on the job, we must not limit our thinking to a narrow or singular factor for hiring the best candidate.

So the question arises: Is an Ivy League education worth 4.5 to 8 times the price of tuition of a major state university? Does the price differential mean an Ivy League graduate has 4.5 to 8 times better chance to succeed or achieve excellence in one's field? Given the issue of student debt, is the extra expense of about $\$ 35,000$ per year or $\$ 140,000$ total worth attending an Ivy League school? Is going to college in general worth the cost? Most "experts" say yes, because college graduates have a lower unemployment rate and earn more money than without a degree. But a growing number of college graduates who must pay the debt are questioning whether a college education justifies the debt burden from private colleges. As The Wall Street Journal pointed out that from 2005 to 2012, the average college loan debt increased 35 percent, adjusting for inflation, while the median salary of college graduates dropped 2.2 percent. A New York Times 
survey put the decline in salary at 4.6 percent, or about $\$ 2000$ a year, adjusted for inflation.

In short, graduates lucky enough to find good jobs will face reduced salaries while a large number will search to find work or settle for under-employed positions and lower-paid positions that do not necessarily require a college degree. Even when the economy recovers, some graduates will never catch up in the job market, effecting lifetime career opportunities and lifetime earnings. The biggest misconception is that a college degree guarantees a good job. That type of thinking represents the pre-smart phone era and the pre-digital world, prior to the $21^{\text {st }}$ century.

An opposing view is set forth by economists Jason Abel and Richard Dietz [1] who argue that despite rising tuition and fewer job prospects among college graduates in recent years, it still pays to graduate from college. Their study, Do The Benefits of College Still Outweigh the Costs?, examined data from 1970 to 2013. They found that college graduates earned on average $\$ 64,500$ annually while associate degree holders earned $\$ 50,000$ and high school graduates earned $\$ 41,000$. But figuring 45 years of work for a college graduate age 22 to 67 and for a high school graduate, 49 years-from 18 to 67 , the total difference ( $\$ 2.9$ million vs. 2 million) is only $\$ 900,000$. If we only consider monetary differences, investing the $\$ 200,000$ at 4 percent interest when the individual is age 18 is a wiser choice.

There are still other proponents who argue that certain colleges which emphasize engineering, mining, or technology enjoy a higher rate of return on investment than other colleges and/or fields of study. According to PayScale, the top median salaries of college graduates in the US in descending order were from Harvey Mudd College (\$2.1 million), California Institute of Technology, Polytechnic Institute of New York, MIT, SUNY-Maritime College, Colorado School of Mines, Stevens Institute of Technology, and Stanford University (\$1.4 million) [2]. The criticism of the survey is that earnings were self-reported and only considered the return on investment for a bachelor's degree. Hence, the data is still uncertain for determining if it's worthwhile to pay a premium for a particular college or major. In the end, the major seems more important than the college. Teachers or social workers graduating from Harvard will not be high earners. Moreover, consider the college with the highest return of investment, Harvey Mudd (\$2.1 million) with a $\$ 200,000$ investment at age $18 \%$ at $6 \%$ return; the investment yield ( $\$ 3.7$ million) is considerably higher. In short, there may be too much hype and optimism about getting a college education.

Don't ever assume that college is the only answer for achieving economic independence or success. The sorting-out process in the US gives the edge to the business person and techie that may not necessarily have a college degree, as well as the entertainer or sports figure. What a college degree seems to guarantee, if we consider all types of careers, is a lower-middle class job. The rest of the mix is related to social skills, networking, politics, and luck. In short, the identification of talent is not perfect and neither is the sorting-out process. The result is some 
confusion and room for disagreement over the value of a college education, and to what extent it is related to future earnings in a white-collar career. For example, the argument can be made that American students are over educated, given the market place. In 2013, 34 percent of Americans ages 25 to 29 had at least a bachelor's degree, compared to 25 percent in 1995 and 11 percent when the author graduated from college in 1962 (when the gross national product was expanding at twice the rate now). Today, for some jobs, there are 50 to 100 college educated candidates for one opening.

And just to add salt to the discussion, consider the opinion of Laszlo Bock who heads up the hiring at Google. He admits he is willing to hire people without a college degree. He's not concerned about what you know or where you learned it, rather what value you can create with what you know. In fact, several tech companies are turning to the high schools to recruit promising employees, before their freshman year at college. May serve as interns, but they are expected to do real work. Among the well-known companies that get young workers in the door as early as 16 years are Facebook, LinkedIn, Square, Yahoo, etc. Of course, if we want an informed citizenry or a baseline for cultural literacy, college has value. If you go to college, you need to acquire more than broad knowledge. You need to acquire skills for the workplace and the ability to apply knowledge and work with data in a logical and systematic way. Going to Harvard or Yale does not necessarily guarantee this kind of outcome. One might even argue that people who have these traits and get accepted to Ivy League schools could develop the same analytical thought processes at state colleges such as Chapel Hill or Ohio State.

Barney Hartford, the CEO of Orbitz Worldwide, is concerned for the trajectory of the candidate's resume. To get to your current position, "was it a steep trajectory?" Did it take you five or ten years to reach this level of achievement, "because that's going to be predictive of what you are going to do within our company... I'm looking for people who've got passion, energy and curiosity, and I really emphasize that over specific experience or education." The right person with the right aptitude and attitude "can within a week [add] immense value to the organization... You want someone who can learn fast and who will be able to adapt as the organization adapts." That can be someone from Hofstra or Harvard, or from a state university or a person who graduated from a community college. In general, the nature of adult learning and learning on the job will often depend on a person's interests, motivation and abilities-and how much overall effort he or she wants to put in to improve on the job. Most of us are suckers for a person from Harvard or Yale-not fully grasping there are all kinds of ways to get into Ivy League colleges, ranging from parental networking, alumni relations and parental donations.

\section{Topic 2: Power, Privilege, and Elite Institutions}

The Ivy League colleges were built on the premise of educating the children of 
the elite class, originally when young men graduated from the Latin School in New England colonies and into the mid-twentieth century when they graduated from private academies like Groton, Choate, and Exeter, which are modern "knockoffs" of the old Latin School. Presidents Franklin Roosevelt, John Kennedy, and both Bush presidents were graduates of these private academies and moved easily to Harvard and Yale, despite their "so-so" academic achievement.

Up to the 1930s, most people who applied to Harvard and Yale, and other places like Princeton and Dartmouth, were admitted because people who were not from the proper social class did not bother applying, as they knew better than to waste their time. The history of admission into these elite colleges is the history of the conflict between merit and privilege. The voices of reform began to conflict with the voice of tradition over what kind of applicants to accept and to what extent should class, alumni status, and social connection trump academic ability and scholarship. According to Jerome Karabel [3], a sociologist from Berkeley, it was not until the Jews began to apply-students who prized scholarships, academic achievement, and high test scores-that the Ivy League colleges faced a dilemma.

Slowly and grudgingly, the Ivy League colleges modified their anti-Semitic policies and allowed a small number of Jews into their institutions, although the number was restricted. Embodied by the spirit of the American dream, so characteristic of all immigrant groups, these striving Jews were merely seeking bits and pieces of the opportunity that their parents had been denied in Europe. For readers who fail to grasp the historical and contextual meaning, the story is played out in Chariots of Fire, some thirty-five years ago. Although the movie takes place at Cambridge University in England, all the reader needs to understand is that Harvard, Yale, Princeton, etc. are forged on the basis of Oxford and Cambridge universities.

Despite the shocked reaction of the Protestant establishment, the genie had been released from the bottle by aspiring Jews and once freed it paved the way for other high-achieving immigrant groups to apply; and, later, minority groups wanted the American dream. In a way, the admissions processes at Harvard and Yale, among other Ivy League colleges, provide a valuable preview of the coming civil rights movement that was to soon explode, where the democratic forces of fairness, equality, and equity were pitted against the traditional forces of protection and privilege. (You can say that this battle has been waged since Jefferson crossed swords with Hamilton, or as far back as the Greeks who tried to forge their theories of democracy in the town squares of Athens and Delphi, the latter which was considered by the Greeks as the center of the world).

Given the beginning of the Cold War in the late 1940s and early 1950s, and the need to produce scientists and engineers to defend against Soviet expansion, the faculties at Ivy League colleges slowly began to stress academics. At the same time, James Conant was president of Harvard. He was the most influential educator of the midcentury, and when he spoke the educational establishment lis- 
tened. Conant urged that American schools and colleges add academic rigor to the curriculum, upgrade teacher training, test and measure students' achievement, and devote more resources for the education of the top academic 20 percent, especially the gifted and talented students.

The Boston Brahmin's idea of “The Harvard Man” was much more progressive than "The Yale Man," as perceived by Yale's president Alfred Griswold, who, in 1950, reassured the Protestant establishment and Yale alumni that the future graduate would not be a "beetle-browed, highly specialized intellectual, but a well-rounded man." Well-rounded, of course, implied you could lack academic credentials, so long as you were well connected or from the right patrician family. Your chances of admission were just fine.

The injustices that were once imposed on over-achieving Jewish students are now directed at over-achieving Asians. To get into an Ivy League School, Asian students need about 120 to 140 points more than whites on SAT tests. They compromise about 15 to 20 of the Ivy League enrollments, but makeup about 50 percent of the applicants with the highest SAT scores, according to one Harvard professor. Today, the excuse to cap Asian students range from a need to balance the racial/ethnic student body, the desire to recruit other minority students, and to recruit other students with leadership potential and/or strong "extra-curricular" backgrounds. Some of these traits sound vague and are purposely designed to help non-Asian students-other minorities and whites-and to limit a true meritocracy. Indeed, the decision to admit various groups of students, and just how many in each group has political, social, and moral tradeoffs. Who gets to go to an Ivy League school has an impact on future opportunities and competitive success. Do we make excellence the chief criteria? What form of excellence? And who decided the form it should take? Are there other considerations? Like who would make the most of their education? Who would most likely become a future leader? Who would most benefit the larger society? There are no right answers, only various beliefs based on human bias.

The conflict between meritocracy versus the well-rounded student persists today by nuance-by putting as much emphasis or more on "character" than academics. Academic merit is but one of many criteria used to judge applicants along with social skills, leadership skills, and creative/artistic skills. All these set of skills, along with alumni linkage, are designed to allow sufficient flexibility to preserve the status quo and power of these institutions, to ensure that "well rounded" students are sought and accepted. The balance between academic mediocrity and merit has permitted and still permits children of the rich and powerful to be admitted because of hereditary privilege. Today, family legacy determines about 20 to 30 percent of Ivy League admissions; that is, about four to five times the overall admission rate.

At Princeton, it is estimated by Michael Hurwitz [4] in Economics of Education Review that legacy is equivalent to 160 additional points on the applicant's SAT score. To be sure, the deck is still stacked in favor of the rich at Ivy League 
schools. Despite the rise of a new educated class, men and women of high academic caliber who were unable to go to Harvard or Yale, or the likes of Princeton and Dartmouth, had to "settle" for the University of Michigan, University of Wisconsin, or University of Illinois-all top-notch colleges, but not part of the cultural and financial elite, not part of the Protestant and corporate establishment. Most people still believe that a college education is the key to remaining in the middle or upper class or rising from a lower to higher class. However, they now worry about rising costs of tuition. One method for choking the opportunity of students from a modest background is to limit financial scholarships and the government funding of Pell Grants.

In context with today's sorting and selection process and notion of "success," the elite institutions are "churning out drones," who are lining up to get jobs in finance and corporate America, according to William Deresiewicz's [5] book Excellent Sheep. He probes the "miseducation" of America's elite students. We've created a generation of "polite, striving, ... [and] grade-grubbing nonentities, who just want to make money." Ivy league education has been perverted, the ex-Yale professor claims, turning out students who are afraid to follow their dreams, instead obsess about tests and grades and extracurricular activities in order to attend Harvard, Yale, etc., and work for J.P. Morgan and Goldman Sachs. Colleges encourage this funneling process; lining up future donors a generation in advance. Those students who go into public service, the arts, or not-for-profit agencies are considered “do gooders" and are tolerated as moral balancing wheels; someone possibly for alumni to remember and brag about.

We all know students whose growth and learning can be explained in terms of motivation, curiosity and creativity-and a desire to write, compose or invent. In general, the students at Harvard, Yale etc. have a different type of ambitionto make money or wield power. Their talent and inner drive is highly focused at the expense of ignoring other gifts and abilities. Their notion of excellence has little to do with serving the common "good" or helping others; it is limited to reinforcing their sense of superiority and privilege. Talking about climate change, organic farms or the Boy Scouts is a way of fooling others at neighborhood parties or soccer fields, that is letting themselves off the hook, or portraying a socially sensitive façade.

It is suffice to add one more wrinkle to the equation. While overt racial and religious discrimination has been eliminated from the college admission process, as has overt quotas based on affirmative action which discriminate in general against white candidates, race remains a qualification for college admission and job applications. Under the guise of diversity, it is important for colleges and corporations to display a "sufficient" number of minorities. It's not necessarily based on the need to compensate for past injustices, as was the original intent, rather now to generate diverse thinking and experiences on college campuses and to expand business markets and serve clients among customers who prefer to work with members of their own race. Indeed, the racial factor is slippery but 
widely used, so we need to make sure that it doesn't block opportunities for ordinary white candidates who have their own disadvantages based on class. Reasonable people may disagree on affirmative action policies, but in an age of meritocracy it is harder to explain why children of Ivy League alumni, usually rich children, should have this advantage, which is nothing more than a heredity-based privilege. All it does is reinforce inequality and reduce educational opportunity for bright students.

For example, if we compare high school and college students with the same standardized test scores who come from different socio-economic backgrounds, we find that their educational outcomes reflect their parents' income, not test results. Students from lower- and moderate-family incomes who want a college education run into a host of problems along the way, and many never get their degrees. Nearly 45 percent of US students who start at four-year colleges haven't earned their degrees after six years. This trend correlates with one major variable-how much their parents earn.

As wages for the working class and middle class remain nearly frozen and college costs continue to spike, higher education opportunity has become increasingly limited and stratified. Every year college students from moderate family incomes are more likely to attend community colleges, where tuition costs average about $\$ 5000$ or less per semester or $10 \%$ of the tuition of elite private colleges. But graduation rates at community colleges are considerably lower than at selective institutions, and those who graduate are much less likely (about 3 percent) to attend elite colleges, while nearly everyone graduates and has a chance at competitive success.

The promise of social and economic mobility in the US and elsewhere depends on devising appropriate solutions. One method is to reduce the rewards of competitive success and the costs of mediocrity. Instead of trying to make more people good at the job, one option is to provide safety nets which ensure a minimum reward level for a particular geographical area (state or province) with an agreed minimum standard of living. It's easier, however, to make selective colleges more accessible to working-and middle-income students and provide greater transfer links from community colleges and selective colleges. This method should be acceptable to people who are concerned with and oppose limiting the rewards for hard work, sustained effort, and differential performance.

If the upper class seizes the benefits of an education (say by directing their children into private schools or by spending in public schools twice or three times as much money in property taxes on their children as low-income children and by ensuring their children are admitted to Ivy League schools), and seizes the gains of national productivity, as they have in past decades, we have a situation where the advantaged group "ruthlessly exploits its position to ensure the dominance of its class." Surprisingly, these are the words of David Brooks [6], the New York Times columnist and the liberal's favorite conservative. Members of the upper class are more likely to inter-marry, which "is really a ceaseless effort to refortify class and solidarity and magnify social isolation," and thus per- 
petuate their dominant position.

Given his conservative views, Brooks, surprisingly and whimsically urges "uneducated workers of the world [to] unite... You have nothing to lose but your chains." He concludes: "I don't agree with everything in Karl's manifesto, because I don't believe in incessant struggle, but I have to admit, he makes some good points." Brooks has a sense of humor, but he is making a serious point. For the last three decades, the winds of big business have been whipsawing and blowing strong, from coast to coast and through the heartland, financially breaking the lives of many ordinary people, creating a rising scourge of debt, decline, and despair among working- and middle-class America, and leaving everyone behind except the high-end and wealthy elite. To be sure, this is not the America most of us grew up in nor envision and believe in. For the sake of our children and their children, we all hope this is not the America we know when we take our last breath and make peace with the Almighty.

Adding, still, another conservative voice to the mix, in a 2014 New York Times article, "Capitalism for the Masses," Arthur Brooks (no relation to David Brooks), the president of the American Enterprise Institute, defends the capitalist system. He does so, not on materialistic grounds (because the discussion eventually drifts to inequality) but on a moral and humanitarian basis. Capitalism can be analyzed on the basis of helping the majority of people become self-sufficient. It can also be measured on whether people enjoy their job or feel their job helps other people. (In this way a nurse or teacher can feel fulfilled and that their work amounts to something worthwhile.) Whether people work at odd jobs or on Wall Street, as a plumber or professional ballplayer, the important thing is that people feel a sense of achievement and/or success. The fact is in the last 30 years, the percentage of the world population earning $\$ 1$ a day, after considering inflation, and the number of malnourished children in the world, have dramatically declined. The primary reason, according to Brooks, is related to globalization and capitalism.

\section{Topic 3: Conclusion}

Tuition revenues for private colleges are beginning to peak and undergraduate enrollments are sliding downward because of price sensitivity-yielding a smaller pool of traditional students. Over the next several years, smaller private colleges with limited revenue could be in financial trouble and disappear from the higher education map. Part of the problem is the economy, but students increasingly are heading to state universities and community colleges in the US (where costs are often $\$ 5000$ a year or less) to save on tuition. The likes of Harvard and Yale will continue to be in demand, and it will not be surprising if in the near future they curtail or severely limit new students because of demand.

\section{References}

[1] Abel, J. and Deitz, R. (2014) Do the Benefits of College Still Outweigh the Costs? 
Current Issues in Economics and Finance, 20.

[2] Ornstein, A.C. (2016) Excellence vs. Equality: Can Society Achieve Both Goals? Routledge, New York.

[3] Karabel, J. (2005) The Chosen: The Hidden History of Admission and Exclusion at Harvard, Yale and Princeton. Houghton Mifflin, Boston.

[4] Hurwitz, M. (2011) The Impact of Legacy Status on Undergraduate Admissions at Elite Colleges and Universities. Economics of Education Review, 30. https://doi.org/10.1016/j.econedurev.2010.12.002

[5] Deresiewicz, W. (2015) Excellent Sheep. Free Press, New York.

[6] Brooks, A. (2014) Capitalism for the Masses. New York Times.

Submit or recommend next manuscript to OALib Journal and we will provide best service for you:

- Publication frequency: Monthly

- 9 subject areas of science, technology and medicine

- Fair and rigorous peer-review system

- Fast publication process

- Article promotion in various social networking sites (LinkedIn, Facebook, Twitter, etc.)

- Maximum dissemination of your research work

Submit Your Paper Online: Click Here to Submit

Or Contact service@oalib.com 